\title{
Digiajan verkot ja verkostot aluetutkimuksessa
}

Teknologiaa kehitetään ja otetaan käyttöön eri tahtiin eri syistä eri puolilla maailmaa, mutta monissa asioissa fyysiset maiden rajat eivät enää paljon vaikuta kehitykseen, etenkään digitaalisilla alustoilla. Arjessakin kuitenkin tulee vastaa digitaalisen ja reaalimaailman kohtaamisia, joihin ei aina ole ennalta varautunut. Tallinnan kaduilla näin lokakuussa laatikkomaisen kuljetusrobotin, joka oli luultavasti viemässä ruokakauppaostoksia asiakkaan kotiovelle. Virolaisen yrityksen robotit ottavat vielä ensiaskeliaan tai pitäisikö sanoa ensiajeluitaan, ja Suomessakin vastaavia on kokeiltu. Tallinnan kaduilla sujahtelee silti kuljetustehtävissä edelleen enemmän ihmisiä kuin robotteja, esimerkiksi Woltin ja Boltin ravintolakuljetuksia tehden. Kuljetusrobotitkin tarvitsevat Helsingin Sanomien 19.10. julkaiseman artikkelin mukaan avukseen välillä ihmisiä auttamaan niitä kauko-ohjauksella tai aivan "lähitukena" kadun varrella.

Kadulla kulkevat robotit sopivat hyvin mielikuviin tämän päivän Virosta. Viro mielletään nykyään teknologian kehityksessä innovatiiviseksi ja yrittäjyysmyönteiseksi, naapurimaa Venäjä innovaatiopolitiikassaan enemmänkin keskusjohtoiseksi. Venäjän innovaatiopolitiikkaan saamme katsauksen tässä numerossa Salla Nazarenkon artikkelissa.

Tässä Idäntutkimuksen Teknologia-teemanumerossa pääsemme myös muun muassa tutustumaan tiedostojen jakamiseen tarkoitettujen vertaisverkkojen käyttäjien maailmaan Ukrainassa ja lukemaan koronapandemian vauhdittamasta digiloikasta Aleksanteri-instituutin koordinoimissa koulutusohjelmissa sekä virtuaalitapahtumista, jotka lienevät tulleet jäädäkseen myös itäisen Euroopan ja Venäjän tutkimusta ja koulutusta koskeviin kokoontumisiin. Myös esimerkiksi brittiläinen slavistiikan ja itäisen Euroopan tutkimuksen yhdistys BASEES, joka perui vuosien 2020 ja 2021 konferenssinsa kokonaan, on päätynyt vuonna 2022 pitämään lähi- ja etäkonferenssin yhdistelmän.

Teknologia on kiinteä osa arkeamme, ja digitaalisiin aineistoihin ja niiden käyttöön sekä verkkoalustoilla tapahtuvaan kanssakäymiseen liittyy monia tärkeitä näkökulmia teknologian ja sisältöjen äärelle pääsystä ja sovellusten saavutettavuudesta aina sisältöjen tekijänoikeuksiin. Teknologia-teemanumeron vastaavana toimittajana toiminut Ira Österberg pohtii kolumnissaan internetiä ja tieteellisen tiedon saavutettavuutta, Markus Kainu puolestaan tiedesisältöjen säilymistä verkkoalustoilla. Heidän esiin nostamansa oleelliset digiajan ky- 
symykset koskevat toki laajempaakin yhteisöä kuin vain Venäjän ja itäisen Euroopan tutkijoita ja tutkimuksesta kiinnostuneita, mutta on tärkeää myös pohtia aihepiiriä nimenomaan aluetutkimuksen kannalta. Idäntutkimuksen sähköinen arkisto on yksi palapelin osa tässä, kun embargon sulkeuduttua lehden vanhemmat numerot tulevat kukin vuorollaan kaikille avoimesti luettaviksi.

Helsingissä 21.10.2021

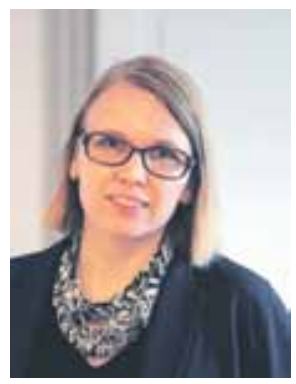

Katja Lehtisari 